\title{
RESPONSES TO THE INJECTION OF EPINEPHRINE IN HEPATIC DISEASE
}

\author{
By ROBERT F. LOEB, ESTHER B. REEVES AND H. PELHAM GLASIER
}

(From the Department of Medicine, College of Physicians and Surgeons, Columbia University, and the Presbyterian Hospital, New York)

(Received for publication September 30, 1930)

\section{INTRODUCTION}

The important rôle of the liver in carbohydrate metabolism has been repeatedly emphasized in recent years, and particular attention has been paid to its function in the maintenance of the blood sugar level and the storage of glycogen $(1,2)$.

Minkowski (3), in 1886, observed the hypoglycemia which developed in geese following hepatectomy and also noted, in the same experiments, a great increase in the urinary excretion of lactic acid. In 1912, Parnas and Baer (4) demonstrated the rôle of the liver in synthesizing glycogen from lactic acid. In 1906, von Noorden and Embden (5) suggested the existance of a "chemical carbohydrate cycle" in which liver glycogen is converted into glucose, which in turn is polymerized in the muscles to glycogen, which then yields lactic acid, and the latter is transported back to the liver to be converted again into carbohydrate. Barr, Himwich, and Green (6) in 1923 demonstrated that lactic acid liberated from leg muscles during exercise is temporarily stored in resting muscles elsewhere. Janssen and Jost, (7), found that during the infusion of d-lactic acid, this substance is removed by the muscles, but with the discontinuation of the infusion, enormous quantities of lactic acid are poured into the venous blood from the muscles and are then presumably synthesized into glycogen by the liver. In the past three years, the carefully controlled experiments of Cori and Cori (9) on the mechanism of the action of epinephrine have yielded quantitative evidence supporting the idea of this carbohydrate cycle and have demonstrated the importance of the liver in the cycle. These authors have pointed out that epinephrine decreases carbohydrate utilization in the muscles, increases the mobilization of muscle glycogen, thus augmenting lactic acid formation, which subsequently increases the glycogen storage in the liver. They have also pointed out that epinephrine hyperglycemia results from an initial but transient glycogenolysis in the liver and that the hyperglycemia is then maintained by the decreased glucose utilization on the part of the muscles. 
On the basis of the work described, numerous clinical studies have been made on the behavior of the lactic acid and of the blood sugar in the presence of liver disease (10-20). In general it has been shown that: $(a)$ the lactic acid content of the blood is increased in patients with severe liver disease; $(b)$ there is a delay in the disappearance of sodium lactate injected intravenously; $(c)$ feeding of sodium lactate occasionally raises the blood lactic acid level more in patients with liver disease than in normal individuals; $(d)$ the hyperglycemia following the injection of epinephrine is less marked in cases of hepatic insufficiency than in those with normal livers, probably because of decreased glycogen stores.

In 1923, Tolstoi et al. (8) found an increase in the lactic acid content of the blood of four normal individuals following the injection of 15 minims of adrenalin. Cori and Cori (9) have recently demonstrated that following the injection of epinephrine in normal animals, there is not only prolonged elevation of the blood sugar but that the lactic acid content of the blood is also increased for some hours. They have observed, furthermore, that the rise in concentration of lactic acid in the venous blood is considerably greater than that in arterial blood. This result is to be expected in view of experiments showing increased glycogen storage in the liver one or more hours after the injection of epinephrine.

From the foregoing discussion it is apparent that the injection of epinephrine causes a prolonged out-pouring of lactic acid from the muscles, which is normally removed by the liver and resynthesized to glycogen. It seemed possible that this mechanism might be interfered with in patients with disease of the liver, and that there would result a greater accumulation of lactic acid in the blood than would be found in normal individuals. For this reason we have studied the blood lactic acid curves following the subcutaneous injection of adrenalin, and simultaneously the changes in blood sugar and blood pressure have been observed.

\section{EXPERIMENTAL}

The studies were made on human subjects in the fasting state and at rest in bed. The "normal" group of controls, except for one medical 
student who was ambulatory, consisted of ward patients in whom no pathological condition could be demonstrated. The cases of jaundice investigated included the following groups of conditions: $(a)$ intrahepatic jaundice including catarrhal jaundice, toxic hepatitis and acute yellow atrophy of the liver; $(b)$ obstructive jaundice due to carcinoma of the pancreas or bile ducts; $(c)$ cirrhosis of the liver; $(d)$ cholecystitis with cholelithiasis. Observations were also made on a group of miscellaneous disease conditions and on six patients suffering from diabetes mellitus.

Blood was withdrawn from an arm vein without stasis and the blood pressure was measured. Following this, 0.7 to $1.0 \mathrm{cc}$. of epinephrine (Armour and Co.) was injected subcutaneously. The blood pressure was determined at intervals of 2 to 3 minutes for one-half hour and at intervals of about 5 minutes during the next thirty minutes. Samples of venous blood were removed one-half, one, and frequently two hours after the adrenalin injection. Blood samples were treated with sodium fluoride and were analyzed without delay for glucose and lactic acid. In the earlier experiments, sugar alone was determined. In later studies blood was not taken two hours after epinephrine injection, because experience demonstrated that the maximum concentrations of sugar and lactic acid were almost invariably reached in one hour.

In a few instances lactic acid was determined in the urine excreted during the two hours following the administration of adrenalin, but as there was no increase over the normal amount, this procedure was discontinued. On the basis of the experiments of Jervell (14) and of Hewlett, Barnett and Lewis (21), no increase in urinary excretion of lactic acid was to be expected.

Lactic acid was determined by the method of Friedemann and Kendall (22) modified in some of its details. The procedure gave excellent results with pure lactate solutions, but was not reliable within \pm 5 per cent when applied to blood or urine samples. The determinations were made on protein-free filtrates of whole blood. The method of Folin and $\mathrm{Wu}$ (23) was used for blood sugar measurements. All analyses were made in duplicate. The lactic acid and the glucose of the blood have been recorded in terms of millimols per liter so that comparative changes in molar concentrations might be observed. 
TAB:

Effect of epinephrine in normal individua

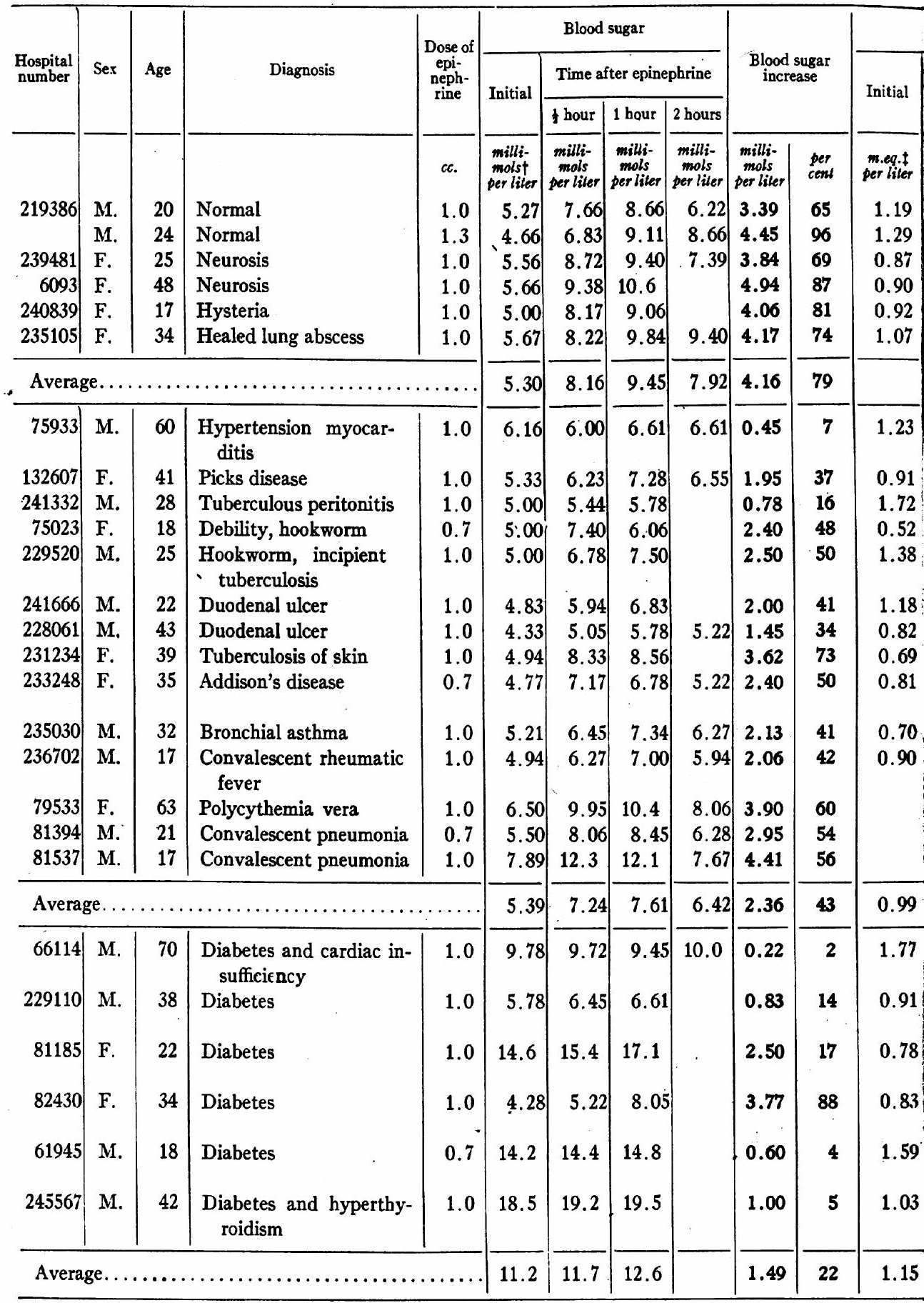

* Patient had severe collapse 40 minutes after epinephrine. Blood pressure dropped to $60 / 30 \mathrm{~mm}$. $\dagger 1$ millimol of glucose $=180 \mathrm{mgm}$.

$\ddagger 1$ milli-equivalent of lactic acid $=90 \mathrm{mgm}$. 
als and in miscellaneous disease conditions

\begin{tabular}{|c|c|c|c|c|c|c|c|c|c|}
\hline \multirow{2}{*}{\multicolumn{3}{|c|}{$\begin{array}{l}\text { Blood lactic acid } \\
\text { Time after epinephrine }\end{array}$}} & \multirow{3}{*}{\multicolumn{2}{|c|}{$\begin{array}{l}\text { Blood lactic } \\
\text { acid increase }\end{array}$}} & \multicolumn{4}{|c|}{ Blood Pressure } & \multirow{3}{*}{ Remarks } \\
\hline & & & & & \multirow{2}{*}{ Initial } & \multirow{2}{*}{$\begin{array}{l}\text { Maxi- } \\
\text { mum }\end{array}$} & \multirow{2}{*}{$\begin{array}{l}\text { In- } \\
\text { crease }\end{array}$} & \multirow{2}{*}{$\left|\begin{array}{c}\text { Time } \\
\text { after } \\
\text { epineph- } \\
\text { rine }\end{array}\right|$} & \\
\hline$\frac{1}{2}$ hour & 1 hour & 2 hours & & & & & & & \\
\hline $\begin{array}{c}\text { m.eq. } \\
\text { per liter }\end{array}$ & $\begin{array}{l}\text { m.eq. } \\
\text { per liler }\end{array}$ & $\begin{array}{c}\text { m.eq. } \\
\text { per liter }\end{array}$ & $\begin{array}{c}\text { m.eq. } \\
\text { per liter }\end{array}$ & $\begin{array}{l}\text { per } \\
\text { cent }\end{array}$ & mm. Hg. & mm. Hg. & $\begin{array}{l}\text { per } \\
\text { cent }\end{array}$ & minutes & \\
\hline 2.98 & 3.62 & 1.87 & 2.43 & 204 & $124 / 70$ & $162 / 40$ & 31 & 35 & \\
\hline 2.63 & 3.30 & 2.93 & 2.01 & 156 & $128 / 84$ & $156 / 76$ & 22 & 35 & Not in bed \\
\hline 1.85 & 2.08 & 1.43 & 1.21 & 139 & $114 / 73$ & $132 / 70$ & 16 & 31 & \\
\hline 2.92 & 3.52 & & 2.62 & 291 & $110 / 70$ & $140 / 50$ & 27 & 18 & \\
\hline 2.14 & 2.57 & & 1.65 & 183 & $100 / 70$ & $140 / ?$ & 40 & 17 & \\
\hline \multirow[t]{2}{*}{2.02} & 2.86 & 2.11 & 1.79 & 167 & $108 / 75$ & $142 / 78$ & 22 & 53 & \\
\hline & 2.99 & 2.09 & 1.95 & 190 & & & 26 & & \\
\hline 1.32 & 1.82 & 1.89 & 0.66 & 54 & $220 / 112$ & $236 / 120$ & 2 & 43 & \\
\hline 1.85 & 2.00 & 1.46 & 1.09 & 120 & $108 / 66$ & $130 / 72$ & 20 & 13 & \\
\hline 3.23 & 3.31 & & 1.59 & 93 & $110 / 80$ & $124 / 70$ & 11 & 12 & Temperature $101^{\circ}$ to $102^{\circ}$ \\
\hline 1.88 & 1.64 & & 1.36 & 262 & $105 / 0$ & $162 / 70$ & 54 & 4 & No anemia. Debilitated \\
\hline 2.11 & 2.59 & & 1.21 & 88 & $112 / 55$ & $134 / 53$ & 20 & 27 & No anemia or fever \\
\hline 2.03 & 2.48 & & 1.30 & 110 & $105 / 60$ & $112 / 60$ & 7 & 3 & Receiving Sippy diet \\
\hline 1.57 & 1.87 & 2.07 & 1.25 & 153 & $116 / 78$ & $142 / 70$ & 22 & 40 & Receiving Sippy diet \\
\hline 1.71 & 1.71 & & 1.02 & 148 & $110 / 72$ & $200 / 108$ & 82 & 15 & \\
\hline 2.11 & 1.55 & 1.10 & 1.30 & 161 & $103 / 78$ & $106 / 70$ & 3 & 10 & $\begin{array}{l}\text { Bilateral adrenal tuberculosis at } \\
\text { autopsy }\end{array}$ \\
\hline 1.39 & 1.43 & 1.12 & 0.73 & 104 & $110 / 80$ & $134 / 84$ & 22 & 58 & \\
\hline 1.93 & 2.33 & 1.39 & 1.43 & 159 & $\begin{array}{r}102 / 62 \\
140 / 92 \\
98 / 60 \\
115 / 62\end{array}$ & $\begin{array}{l}128 / 70 \\
196 / 70 \\
138 / 50 \\
178 / 76\end{array}$ & $\begin{array}{l}25 \\
40 \\
41 \\
55\end{array}$ & $\begin{array}{r}37 \\
\\
28 \\
21 \\
7\end{array}$ & $\begin{array}{l}\text { Lactic acid excreted in urine }=15.9 \\
\text { mgm. }\end{array}$ \\
\hline 1.92 & 2.07 & 1.51 & 1.18 & 132 & & & 29 & & \\
\hline 1.26 & 1.38 & 1.78 & 0.01 & 0 & $160 / 96$ & $192 / 106$ & 20 & 107 & Not using insulin. Sugar free. \\
\hline 1.41 & 2.29 & & 1.38 & 152 & $98 / 68$ & $112 / 65$ & 14 & 3 & $\begin{array}{l}\text { Insulin on night before test. Urine } \\
\text { sugar free }\end{array}$ \\
\hline 1.54 & 2.03 & & 1.25 & 160 & $118 / 82$ & $128 / 58$ & 8 & 44 & $\begin{array}{l}\text { Insulin on night before test. Urine } \\
\text { sugar }++\end{array}$ \\
\hline 0.84 & 1.64 & & 0.81 & 98 & $120 / 75$ & $148 / 55$ & 23 & 38 & $\begin{array}{l}\text { Insulin on night before test. Sugar } \\
\text { free }\end{array}$ \\
\hline 1.46 & 1.81 & & 0.22 & 13 & $114 / 74$ & $140 / 66$ & 23 & 53 & $\begin{array}{l}\text { Insulin on night before test. Urine } \\
\text { sugar }++\end{array}$ \\
\hline 2.40 & 2.93 & & 1.90 & 185 & $108 / 60$ & $168 / 80$ & 56 & $28^{*}$ & $\begin{array}{l}\text { Insulin on night before test. Urine } \\
\text { sugar }+++\end{array}$ \\
\hline 1.49 & 2.01 & & 0.85 & 101 & & & 24 & & \\
\hline
\end{tabular}

Hg. Recovery in $\mathbf{5}$ minutes. 


\section{RESULTS}

In the first section of table 1 it may be seen that in response to the subcutaneous injection of epinephrine into normal individuals, the blood sugar increases about 80 per cent above the fasting level, the lactic acid rises about 200 per cent and an increase of about 25 per cent occurs in the systolic blood pressure. The values for sugar and lactic acid reach a peak at the end of one hour, whereas the blood pressure begins to fall before this time. This chronological relationship for maximal effects is approximately the same in all of the groups of patients studied. While there is a rather striking uniformity in the degree of blood sugar increase among the members of the normal group, the same can not be said of the blood lactic acid although the rise of the latter is in all cases greater than 130 per cent.

In the second section of table 1 are shown the results obtained in a miscellaneous group of disease conditions. The results are qualitatively like those found in normal individuals, but it may be observed that the average increase in blood sugar and lactic acid is about half as great as in the normals. The average blood pressure response is approximately the same as in the healthy subjects. The variations in this miscellaneous group are naturally great.

The blood sugar and lactic acid curves of the diabetic patients, seen in the last section of table 1 , show a still greater deviation from the normal. The average response of the blood sugar in these cases is only about 25 per cent as great as in the normal group, although the fasting level is naturally high, and lactic acid increases, on the average, only half as much as in healthy individuals. The effect on blood pressure is approximately normal. All of these patients were in a state of good nutrition.

The reactions of the blood sugar, blood lactic acid and blood pressure to the injection of epinephrine in patients with jaundice are summarized in table 2. In the first group, which embraces the cases of intrahepatic jaundice, it will be observed that the blood sugar response is about one third of the normal, while the average increases in lactic acid concentration and in systolic blood pressure are approximately the same as those found in healthy subjects. The individual variations in this group are great, and many of the patients showed a definite elevation of the initial lactic acid values as has been observed by 
Adler and Lange (11), Beckmann (12), Schumacher (10) and others. The cases of obstructive jaundice (the second group in table 2) due to carcinoma without liver metastases showed still less response on the part of the blood sugar and lactic acid to adrenalin, and in this group the elevation of the systolic blood pressure is distinctly less than in any other group. The high initial blood sugar values result from the presence of mild diabetes in some of the patients.

The studies of patients with cirrhosis are unfortunately incomplete, but in this group the blood sugar response is of the same order as in all the other types of liver disease and jaundice investigated.

In the last section of table 2 are presented the results obtained in the study of three cases of cholecystitis and cholelithiasis. The group is small but it may nevertheless be observed that in these cases too, there is an abnormally small increase in blood sugar and lactic acid after epinephrine as in the cases of obstructive jaundice, while the blood pressure rise is approximately normal.

In none of the groups of cases studied was there definite molecular correlation between changes in blood sugar and blood lactic acid resulting from the administration of adrenalin. Furthermore, no constant relationship was established between the concentration of bilirubin in the serum and the response of the carbohydrate metabolism to epinephrine.

\section{DISCUSSION}

Brill and Fitz-Hugh (16) first showed that the blood sugar curves resulting from epinephrine injection are lower in the presence of liver disease than those obtained in healthy individuals, but believed that this test is of little clinical value. Kugelmann (19) in 1929 confirmed the findings of Brill and Fitz-Hugh and concluded that the test is of importance in differentiating parenchymatous liver damage from obstructive jaundice, as three cases of carcinoma of the pancreas showed a normal blood sugar response. This latter observation is at variance with our results which showed that the slope of the sugar curve in obstructive jaundice is just as low as in the cases of intrahepatic jaundice. There was no definite correlation between the severity of the liver damage and lack of blood sugar response to adrenalin. It is significant that not only in hepatic disease but also in a group of 
Effect of epinephrine in va

\begin{tabular}{|c|c|c|c|c|c|c|c|c|c|c|c|}
\hline \multirow{3}{*}{$\begin{array}{c}\text { Hospital } \\
\text { number }\end{array}$} & \multirow{3}{*}{ Sex } & \multirow{3}{*}{ Age } & \multirow{3}{*}{ Diagnosis } & \multirow{3}{*}{$\begin{array}{l}\text { Serum } \\
\text { bili- } \\
\text { rubin }\end{array}$} & \multirow{3}{*}{$\begin{array}{l}\text { Dose of } \\
\text { epi- } \\
\text { neph- } \\
\text { rine }\end{array}$} & \multicolumn{4}{|c|}{ Blood sugar } & \multirow{2}{*}{\multicolumn{2}{|c|}{$\begin{array}{c}\text { Blood sugar } \\
\text { increase }\end{array}$}} \\
\hline & & & & & & \multirow{2}{*}{ Initial } & \multicolumn{3}{|c|}{ Time after epinephrine } & & \\
\hline & & & & & & & hour & 1 hour & 2 hours & & \\
\hline & & & & $\underset{\text { per cent }}{\text { mgm. }}$ & cc. & $\begin{array}{c}\text { milli- } \\
\text { molst } \\
\text { per hiter }\end{array}$ & $\begin{array}{c}\text { milli- } \\
\text { mols } \\
\text { per liter }\end{array}$ & $\begin{array}{c}\text { milli- } \\
\text { mols } \\
\text { per litiler }\end{array}$ & $\mid \begin{array}{c}\text { milli- } \\
\text { mols } \\
\text { per liter }\end{array}$ & $\left|\begin{array}{c}\text { milli- } \\
\text { mols } \\
\text { per liter }\end{array}\right|$ & per cent \\
\hline 162207 & M. & 15 & Catarrhal jaundice & + & 0.7 & 5.44 & 7.17 & 6.94 & & 1.73 & 32 \\
\hline 241391 & M. & 27 & Catarrhal jaundice & 6.7 & 1.0 & 5.44 & 6.00 & 6.67 & 6.67 & 1.23 & 23 \\
\hline 236877 & M. & 42 & Catarrhal jaundice & 7.1 & 1.0 & 5.72 & 6.72 & 8.00 & 6.72 & 2.28 & 40 \\
\hline 230476 & M. & 39 & Catarrhal jaundice* & 12.1 & 1.0 & 5.72 & 6.22 & 7.11 & 6.50 & 1.39 & 24 \\
\hline 247298 & M. & 50 & Catarrhal jaundice* & 25.0 & 1.0 & 6.17 & 6.00 & 6.00 & 5.83 & $|-0.34|$ & -3 \\
\hline 249288 & M. & 26 & Catarrhal jaundice* & 18.8 & 1.0 & 5.10 & 5.61 & 6.33 & 6.00 & 1.23 & 24 \\
\hline 81288 & M. & 45 & Catarrhal jaundice* & 10.7 & 1.0 & 6.11 & 5.89 & 6.72 & 6.72 & 0.61 & 10 \\
\hline 80130 & F. & 34 & Arsphenamine jaundice & 4.1 & 1.0 & 4.89 & 5.50 & 5.96 & & 1.07 & 22 \\
\hline 187769 & F. & 40 & Arsphenamine jaundice & 6.8 & 0.7 & 8.44 & 9.78 & 13.2 & & 4.76 & 56 \\
\hline 189511 & M. & 64 & Ars & 8.3 & 1.0 & 4.61 & 4.83 & 6.17 & & 1.56 & 34 \\
\hline 228219 & M. & 33 & Ars & 10.7 & 1.0 & 4.55 & 4.95 & 6.17 & & 1.62 & 36 \\
\hline 217054 & F. & 32 & Arsphenamine jaundice & 15.0 & 1.0 & 4.39 & 5.50 & 6.89 & 5.27 & 2.50 & 57 \\
\hline 82140 & F. & 54 & Acute yellow atrophy & 20.5 & 1.0 & 6.67 & 6.45 & 6.45 & 6.67 & -0.22 & -3 \\
\hline 76301 & F. & 36 & Acute yellow atrophy & 5.4 & 1.0 & 6.28 & 6.56 & 7.45 & 6.67 & 1.17 & 19 \\
\hline \multicolumn{6}{|c|}{ 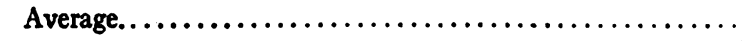 } & 5.68 & 6.23 & 7.15 & 6.34 & 1.47 & 25 \\
\hline 226203 & M. & 65 & f pancreas & 4.7 & 1.0 & 5.56 & 6.29 & 8.84 & 8.70 & 3.28 & 59 \\
\hline 230777 & F. & 52 & Can & 3.2 & 1.0 & 9.45 & 10.0 & 11.1 & 10.6 & 1.65 & 18 \\
\hline 244699 & M. & 59 & Canc & 10.9 & 1.0 & 13.1 & 14.8 & 15.2 & & 2.10 & 16 \\
\hline 80477 & M. & 54 & Canc & 7.6 & 1.0 & 9.22 & 8.56 & 8.12 & 8.90 & -1.10 & -12 \\
\hline 82030 & M. & 41 & Car & 12.5 & 0.7 & 7.39 & 8.34 & 7.11 & & 0.95 & 13 \\
\hline 264809 & M. & 42 & Cancer of pancreas & 21.0 & 0.8 & 5.44 & 5.89 & 7.05 & 5.94 & 1.61 & 30 \\
\hline \multicolumn{6}{|c|}{ Average........................................ } & 8.36 & 8.98 & 9.57 & 8.54 & 1.42 & 21 \\
\hline 245483 & F. & 44 & $\mathrm{H}$ & + & 1.0 & 5.06 & 7.95 & 9.73 & & 4.68 & 93 \\
\hline 81487 & M. & 51 & & + & 1.0 & 6.06 & 7.06 & 6.95 & 6.06 & 1.00 & 16 \\
\hline 81855 & M. & 45 & (?) syphilitic & 6.8 & 1.0 & 6.50 & 6.56 & 7.17 & 6.67 & 0.67 & 10 \\
\hline 69567 & M. & 62 & cirrhosis & 12.5 & 1.0 & 6.12 & 6.72 & 6.72 & 7.06 & 0.94 & 15 \\
\hline 82774 & M. & 62 & Atrophic cirrhosis & & 1.0 & 6.84 & 7.44 & 8.67 & 8.95 & 2.11 & 31 \\
\hline \multicolumn{6}{|c|}{ 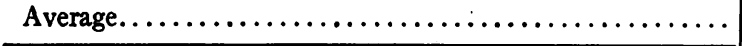 } & 6.12 & 7.15 & 6.85 & 7.19 & 1.88 & 33 \\
\hline 239167 & M. & 71 & $\begin{array}{l}\text { Cholecystitis and chol- } \\
\text { angitis }\end{array}$ & 5.0 & 1.0 & 6.61 & 7.50 & 8.73 & 7.78 & 2.12 & 32 \\
\hline 243940 & F. & 23 & $\begin{array}{l}\text { Cholecystitis and chol- } \\
\text { elithiasis }\end{array}$ & + & 1.0 & 6.06 & 7.40 & 7.06 & & 1.34 & 22 \\
\hline 244726 & F. & 58 & $\begin{array}{l}\text { Cholecystitis and chol- } \\
\text { elithiasis }\end{array}$ & + & 0.8 & 5.28 & 6.56 & 6.95 & & 1.67 & 32 \\
\hline \multicolumn{6}{|l|}{$\mathbf{A}$} & 5.9 & 7.15 & 7.5 & & 1.71 & 29 \\
\hline
\end{tabular}

" Severe jaundice, i.e., "toxic hepatitis."

$\dagger 1$ millimol of glucose $=180 \mathrm{mgm}$.

$\$ 1$ milli-equivalent of lactic acid $=90 \mathrm{mgm}$.

$t=$ trace of bilirubin.

A-blood pressure observed for 20 minutes only.

B-blood pressure fell to $72 / 22 \mathrm{~mm}$. $\mathrm{Hg}$. 70 minutes after epinephrine 
BLE 2

arious types of liver disease

\begin{tabular}{|c|c|c|c|c|c|c|c|c|c|c|}
\hline \multicolumn{4}{|c|}{ Blood lactic acid } & \multirow{3}{*}{\multicolumn{2}{|c|}{$\begin{array}{l}\text { Blood lactic } \\
\text { acid increase }\end{array}$}} & \multicolumn{4}{|c|}{ Blood pressure } & \multirow{3}{*}{ Remarks } \\
\hline \multirow{2}{*}{ Initial } & \multicolumn{3}{|c|}{ Time after epinephrine } & & & \multirow{2}{*}{ Initial } & \multirow{2}{*}{$\begin{array}{l}\text { Maxi- } \\
\text { mum }\end{array}$} & \multirow{2}{*}{$\begin{array}{l}\text { Systolic } \\
\text { increase }\end{array}$} & \multirow{2}{*}{$\begin{array}{c}\text { Time } \\
\text { after } \\
\text { epineph- } \\
\text { rine }\end{array}$} & \\
\hline & $\frac{1}{2}$ hour & 1 hour & 2 hours & & & & & & & \\
\hline $\begin{array}{l}\text { m.Eq: } \\
\text { per liter }\end{array}$ & $\begin{array}{c}\text { m.Eq. } \\
\text { per liler }\end{array}$ & $\begin{array}{c}\text { m. Eq. } \\
\text { per liter }\end{array}$ & per liter & $\begin{array}{c}\text { m.Eq. } \\
\text { per liter }\end{array}$ & $\begin{array}{l}\text { per } \\
\text { cent }\end{array}$ & $m m \cdot B_{g}$ & $m m \cdot \mathrm{Hg}$ & per cent & minules & \\
\hline 0.87 & 2.39 & 2.74 & & 1.87 & 214 & $99 / 50$ & $133 / 46$ & 33 & 17 & \\
\hline 1.53 & 3.70 & 3.77 & 2.33 & 2.24 & 147 & $97 / 62$ & $134 / 54$ & 38 & 15 & \\
\hline 0.86 & 2.22 & 2.31 & 1.47 & 1.45 & 168 & $94 / 64$ & $110 / 64$ & 17 & 50 & $\begin{array}{l}\text { Lactic acid excreted in urine }= \\
17 \mathrm{mgm} .\end{array}$ \\
\hline 1.22 & 2.70 & 3.04 & 2.19 & 1.82 & 149 & $|105 / 62|$ & $140 / 80$ & 33 & 10 & . \\
\hline 1.97 & 3.23 & 4.17 & 3.38 & 2.20 & 112 & $98 / 60$ & $116 / 50$ & 18 & 32 & \\
\hline 0.84 & 1.53 & 1.97 & 1.52 & 1.13 & 135 & $114 / 70$ & $156 / 60$ & 37 & 34 & $\begin{array}{l}\text { Arsphenamine } 13 \text { months before } \\
\text { admission }\end{array}$ \\
\hline & & & & & & $98 / 60$ & $116 / 50$ & 18 & 42 & \\
\hline 2.88 & 3.84 & 3.00 & & 0.96 & 33 & $136 / 80 \mid$ & $220 / 120$ & 62 & 5 & $\begin{array}{l}\text { Operated upon } 4 \text { days later and } \\
\text { died }\end{array}$ \\
\hline 1.49 & 2.39 & 3.21 & & 1.72 & 115 & $90 / 60$ & $110 / 60$ & 22 & 5 & $\begin{array}{l}\text { Infusion of } 10 \text { per cent glucose } \\
\text { night before test }\end{array}$ \\
\hline 1.22 & 1.23 & 2.11 & & 0.89 & 73 & $130 / 70 \mid$ & $136 / 50$ & 5 & 24 & \\
\hline 0.77 & 1.83 & 2.33 & & 1.56 & 202 & $105 / 65$ & $120 / 75$ & 14 & 10 & \\
\hline 1.26 & 3.61 & 5.59 & 4.26 & 4.33 & 343 & $105 ; 70$ & ${ }_{142 / 74}^{14 / 75}$ & $10 \mathrm{~A}$ & 11 & $\begin{array}{l}\text { A tourniquet was used in obtain- } \\
\text { ing blood } \\
\text { Comatose and died next day. } \\
\text { Autopsy } \\
\text { Operated upon. Test done in } \\
\text { convalescence }\end{array}$ \\
\hline 1.36 & 2.61 & 3.11 & 2.53 & 1.83 & 154 & & & 26 & & \\
\hline 1.00 & 1.72 & 1.81 & 2.27 & 1.27 & 127 & $160 \div 50$ & $160 ; 50$ & B & & $\begin{array}{l}\text { Lactic acid excreted in urine }= \\
12.7 \mathrm{mgm} .\end{array}$ \\
\hline 1.11 & 2.94 & 2.72 & 1.39 & 1.83 & 165 & $108 / 70$ & $130 / 70$ & 20 & 20 & Operated upon \\
\hline 1.06 & 2.06 & 2.19 & & 1.13 & 107 & $102 ; 66 \mid$ & $112 / 64$ & 10 & 17 & Operated upon \\
\hline 1.20 & 1.24 & 1.11 & 1.70 & 0.50 & 42 & $\begin{array}{r}112 ; 75 \\
96 ; 68\end{array}$ & $\begin{array}{l}126 / 70 \\
100 ; 58\end{array}$ & $\begin{array}{r}13 \\
4\end{array}$ & $\begin{array}{r}2 \\
19\end{array}$ & $\begin{array}{l}\text { Died } 5 \text { days later. Autopsy } \\
\text { Died. Autopsy }\end{array}$ \\
\hline 0.98 & 1.26 & 1.98 & 1.55 & 1.00 & 102 & $132 / 70 \mid$ & $140 / 58$ & 6 & 51 & $\begin{array}{c}\text { Lactic acid excreted in urine }= \\
8.5 \mathrm{mgm} . \text { Operated upon }\end{array}$ \\
\hline 1.07 & 1.84 & 1.96 & 1.73 & 1.15 & 109 & & & 11 & & \\
\hline 1.18 & 3.13 & 3.57 & & 2.39 & 203 & $\begin{array}{l}112 ; 70 \\
105 ; 75 \\
128 / 82 \\
115 ; 64 \\
122 ; 50\end{array}$ & $\begin{array}{l}170 ; 84 \\
110 ; 75 \\
130 ; 78 \\
140 ; 60 \\
150 ; 58\end{array}$ & $\begin{array}{c}52 \\
5 A \\
2 A \\
22 \\
23\end{array}$ & $\begin{array}{r}10 \\
18 \\
2 \\
77 \\
60\end{array}$ & Operation \\
\hline 1.28 & 2.16 & 2.68 & $\overline{2.00}$ & 1.40 & $\overline{109}$ & $97 / 56$ & $102 ; 66$ & 5 & 24 & Operation \\
\hline 0.80 & 1.31 & 1.72 & & 0.92 & 115 & $122 ; 68$ & $160 / 70$ & 31 & 40 & Proven by $x$-ray examination \\
\hline 1.26 & 1.76 & 2.24 & & 0.98 & 78 & $155 / 60$ & $184 / 50$ & 19 & 30 & \\
\hline 1.10 & 1.74 & 2.21 & & 1.10 & 101 & & & 18 & & \\
\hline
\end{tabular}


miscellaneous diseases in which there was no evidence of liver disorder, the blood sugar response to epinephrine is subnormal.

In five of the six cases of diabetes studied, the blood sugar response to adrenalin was smaller than in any of the groups of liver disease investigated. It is possible that this is the result of the antagonistic action of insulin injected 15 hours before the experiment (9), but this time interval seems entirely too long to serve as an explanation, and furthermore, the same observation was made in one patient who did not receive insulin. In those cases in which sugar was present in the urine at the time of test, any excess sugar liberated by glycogenolysis may have been excreted in the urine without influencing the blood sugar level. The reaction of diabetic patients to adrenalin injection should be further studied.

Adler and Lange (11), Schumacher (10) and Beckmann (12) (18) as well as Wakefield and Greene (20) have demonstrated the increase in the fasting lactic acid content of the blood of patients with liver disease. Our experiments confirm this finding, but this abnormality of the blood is also found in some of our miscellaneous cases and is known to exist in cardiac disease, secondary anemias and in other diseases (14). Furthermore we observed no consistent parallelism between the severity of the liver disease and the height of the initial lactic acid level. On the basis of the theoretical considerations discussed in the introduction, it might be anticipated that following the injection of adrenalin, there would be an abnormally great accumulation of lactic acid in the blood in patients with liver disease. The results showed, contrary to expectation, that there is an abnormally small increase, both actual and relative, in obstructive jaundice and also in disease conditions not associated with pathological changes in the liver. In diseases in which there is degeneration of liver cells (intrahepatic jaundice) the findings approach the conditions which might be theoretically anticipated, i.e., abnormally high blood lactic acid levels after epinephrine, but even here the concentration does not exceed that found in normal individuals. This tendency toward lactic acid retention is, however, indicative of a failure of the liver cells to synthesize glycogen.

The work presented shows clearly that in many pathological states, including diseases of the liver, the response of the carbohydrate metabolism to the injection of epinephrine is quantitatively less than in 
normal individuals; i.e., the diseased subjects act as though they had received a smaller dose of the hormone. It thus seems possible that in certain diseases, some of the effects of adrenalin are inhibited by factors still unknown. It is improbable that this is the result of poor absorption from the subcutaneous tissues as the site of injection was always thoroughly massaged and because of the long duration of the experiments. If this point of view is accepted as a working hypothesis, it renders unnecessary the assumption that the low blood sugar curves, observed in liver disease, are dependent upon depleted hepatic glycogen stores. Moreover this working hypothesis will explain the fact that the lactic acid curves in liver disease tend to be below normal instead of being elevated.

While evidence suggestive of the inhibition of the epinephrine effect on carbohydrate metabolism was found in all of the disease groups studied, the pressor effect was normal except in the cases of obstructive jaundice due to carcinoma of the head of the pancreas. In these patients the blood pressure response was definitely below normal. It is interesting to note in this group, that epinephrine also appeared to have less effect upon the carbohydrate metabolism than in any other of the disease conditions.

\section{CONCLUSIONS}

1. The effect of epinephrine upon the blood sugar, blood lactic acid and blood pressure has been studied in liver disease, as well as in certain other pathological conditions.

2. The rise in blood sugar is less marked in cases of liver disease, diabetes and many other pathological states than in normal subjects.

3 . The blood sugar curve after epinephrine injection is in no way characteristic of liver disease and does not appear to correspond closely to the type or degree of damage present.

4. The lactic acid content of the blood in the postabsorptive period is occasionally increased in hepatic disease. This abnormality is not limited to lesions of the liver, nor is it consistently related to the severity of the process or to the concentration of bilirubin in the blood.

5. Contrary to theoretical expectations, the lactic acid curves resulting from the administration of adrenalin are frequently lower in liver disease, diabetes and certain other pathological conditions than in normal individuals. 
6. It is suggested that the abnormally small response of the blood sugar and lactic acid in liver disease and certain other pathological conditions, notably diabetes, results from an inhibition of the action of epinephrine on carbohydrate metabolism.

7. The pressor effect of epinephrine tends to be the same in normal individuals and patients suffering from liver disorders, except in cases of carcinoma of the pancreas with obstruction of the bile ducts where this effect is decreased.

\section{BIBLIOGRAPHY}

1. Mann, F. C., and Magath, T. B., Ergebn. d. Physiol., 1924, xxiii, 212. Die Wirkungen der totalen Leberexstirpation.

2. Mann, F. C., Medicine, 1927, vi, 419. The Effects of Complete and of Partial Removal of the Liver.

3. Minkowski, O., Arch. f. exp. Path., 1886, xxi, 41. Ueber den Einfluss der Leberextirpation auf den Stoffwechsel.

4. Parnas, J., and Baer, J., Biochem. Ztschr., 1912, xli, 386. Utber Zuckerabbau und Zuckeraufbau im tierischen Organismus.

5. von Noorden, C., and Embden, G., Zentralbl. f. d. ges. Physiol. u. Path., 1906, i, 2. Einige Probleme des intermediären Kohlenhydratstoffwechsels.

6. Barr, D. P., Himwich, H. E., and Green, R. P., J. Biol. Chem., 1923, lv, 495. Studies in the Physiology of Muscular Exercise. I. Changes in Acid-Base Equilibrium Following Short Periods of Vigorous Muscular Exercise.

7. Janssen, S., and Jost, H., Ztschr. f. physiol. Chem., 1925, cxlviii, 41. Utber den Wiederaufbau des Kohlenhydrates im Warmblütermuskel.

8. Tolstoi, E., Loebel, R. O., Levine, S. Z., and Richardson, H. B., Proc. Soc. Exp. Biol. and Med., 1923-24, xxi, 449. The Production of Lactic Acid in Diabetes Following the Administration of Insulin.

9. Cori, C. F., and Cori, G. T., J. Biol. Chem., 1928, lxxix, 309. The Mechanism of Epinephrine Action. I. The Influence of Epinephrine on the Carbohydrate Metabolism of Fasting Rats, with a Note on New Formation of Carbohydrates.

Cori, C. F., and Cori, G. T., J. Biol. Chem., 1928, lxxix, 321. II. The Influence of Epinephrine and Insulin on the Carbohydrate Metabolism of Rats in the Post-absorbtive State.

Cori, C. F., and Cori, G. T., J. Biol Chem., 1928; lxxix, 343. III. The Influence of Epinephrine on the Utilization of Absorbed Glucose.

Cori, C. F., and Cori, G. T., J. Biol. Chem., 1929, lxxxiv, 683. IV. The Influence of Epinephrine on Lactic Acid Production and Blood Sugar Utilization.

Cori, C. F., Cori, G. T., and Buchwald, K. W., J. Biol. Chem., 1930, Ixxxvi, 375. V. Changes in Liver Glycogen and Blood Lactic Acid after Injection of Epinephrine and Insulin. 
10. Schumacher, H., Klin. Wchnschr., 1928, vii, 1733. Das Verhalten der Blutmilchsäure bei Leberkranken.

11. Adler, A., and Lange, H., Deutsch. Arch. f. klin. Med., 1927, clvii, 129. Der Milchsäuregehalt des Blutes bei Leberkrankheiten.

12. Beckmann, K., Klin. Wchnschr., 1927, vi, 2229. Resynthese der Milchsäure bei Störungen der Leberfunktion.

13. Beckmann, K. and Mirsalis, T., Deutsch. Arch. f. klin. Med., 1928, clix, 129. Der Milchsaüregehalt des Blutes nach Milchsaüreinjektion bei experimentellen Leberschädigungen.

14. Jervell, O., Acta Med. Skandin., Supp. 24, 1928, 1. Investigation of the Concentration of Lactic Acid in Blood and Urine under Physiologic and Pathological Conditions.

15. Magreth, G., Boll. d. Soc. ital. di biol. sper., 1928, iii, 518, 519. Sul Contenuto in Acido Lattico del Liquido Cerebro-spinale. Ricerche sul Comportamento dell' Acido Lattico del Sangue.

16. Brill, S., and Fitz-Hugh, T., Jr., Arch. Path., 1928, v, 1148. Epinephrine Glycogenolysis as a Test for Liver Function.

17. Brill, S., Arch. Surg., 1929, xviii, 1803. Glycogenolysis due to Epinephrine in Hepatic Disease.

18. Beckmann, K., Ztschr. f. klin. Med., 1929, cx, 163. Klinische Erfahrungen mit der Leberfunktionsprüfung durch Milchsäurebelastung.

19. Kugelmann, B., Klin. Wchnschr., 1929, viii, 264. 'Das Verhalten der Adrenalin-Blutzuckerkurven bei Erkrankungen des Leberparenchyms.

20. Wakefield, E. G., and Greene, C. H., Ann. Int. Med., 1930, iii, 793. The Lactic Acid Content of the Blood and the Partition of Inorganic Sulphate in the Serum of Patients with Hepatic Disease.

21. Hewlett, A. W., Barnett, G. D., and Lewis, J. K., J. Clin. Invest., 1926-27, iii, 317. The Effect of Breathing Oxygen-enriched Air during Exercise upon Pulmonary Ventilation and upon the Lactic Acid Content of Blood and Urine.

22. Friedemann, T. E., and Kendall, A. I., J. Biol. Chem., 1929, lxxxii, 23. The Determination of Lactic Acid.

23. Folin, O., and Wu, H., J. Biol. Chem., 1920, xli, 367. A System of Blood Analysis. Supplement I. A Simplified and Improved Method for Determination of Sugar. 